\title{
Pidana Cambuk dalam Perspektif Keadilan Hukum dan Hak Asasi Manusia di Provinsi Nanggroe Aceh Darussalam
}

\author{
Natangsa Surbakti \\ Fakultas Hukum Universitas Muhammadiyah Surakarta \\ Jl. A. Yani Pabelan Kartasura Surakarta 57102 \\ natangsas@yahoo.com
}

\begin{abstract}
This research discusses the phenomena on Islamic Criminal Law enforcement by applying whipping in the perspective of justice and human rights. Analysis is based on empirical research result in Nangroe Aceh Darussalam using socio-legal approach. Research data includes regulation related to Islamic Law enforcement and dynamic thought of the actors involved in the enforcement of Islamic Law. The research result shows that the competency of sharia court is limited to some criminal conduct regulated in qanun. Competency is limited to the Islam citizen.
\end{abstract}

Key words: Syaria' court, criminal act, voluntary self submission

\begin{abstract}
Abstrak
Penelitian ini mengkaji fenomena penegakan hukum pidana Islam dengan menerapkan pidana cambuk dilihat dari perspektif keadilan dan hak asasi manusia. Kajian didasarkan pada hasil penelitian empiris di Provinsi Nanggroe Aceh Darussalam dengan menggunakan pendekatan sosio-legal. Data penelitian meliputi aturan hukum yang berkaitan dengan penegakan syariat Islam dan dinamika pemikiran para pihak yang terlibat dalam penegakan syariat Islam. Hasil penelitian menunjukkan bahwa kewenangan mahkamah syariah terbatas pada beberapa jenis tindak pidana yang diatur di dalam qanun, kewenangan mengadili terbatas pada warga yang beragama Islam, adanya upaya penundukkan diri secara sukarela tersangka non-muslim berdasarkan pertimbangan rasa keadilan.
\end{abstract}

Kata kunci : Mahkamah syariah, jarimah, penundukan diri secara sukarela 


\section{Pendahuluan}

Provinsi Nanggroe Aceh Darussalam (NAD) merupakan satu-satunya provinsi dalam Negara Kesatuan Republik Indonesia (NKRI) yang berdasarkan undangundang otonomi khusus memperoleh kewenangan penuh menjalankan syariat Islam. ${ }^{1}$ Pemerintah Republik Indonesia melalui Undang-Undang Nomor 18 Tahun 2001 tentang Otonomi Khusus Bagi Provinsi Nanggroe Aceh Darussalam yang kemudian menjadi Provinsi NAD, selain memberikan kewenangan menjalankan syariat Islam juga memberikan landasan hukum bagi peradilan syariah di Provinsi NAD. ${ }^{2}$ Undangundang ini juga memuat penegasan bahwa kewenangan menjalankan syariat Islam ini merupakan bagian tidak terpisahkan dari otonomi khusus yang diberikan oleh pemerintah pusat sesuai dengan kebutuhan khusus daerah dan masyarakat di wilayah provinsi ini.

Pemberian otonomi khusus kepada Provinsi Nanggroe Aceh Darussalam (NAD), yang di dalamnya termasuk kewenangan penuh menegakkan syariat Islam, merupakan harapan masyarakat Aceh sejak lama. Masyarakat Aceh telah sejak lama dikenal sebagai bumi "serambi Mekah", ${ }^{3}$ sebuah penyebutan yang merefleksikan penghayatan dan pengamalan syariat Islam mewarnai setiap sendi kehidupan masyarakat. ${ }^{4}$

Kewenangan penegakan syariat Islam yang berpayung hukum pada peraturan perundang-undangan pemerintah pusat ini, kemudian ditindaklanjuti dengan dibentuknya sejumlah peraturan daerah untuk wilayah provinsi yang dikenal dengan qanun. ${ }^{5}$ Upaya untuk kepentingan penegakan syariat Islam ini, hingga kini telah dibentuk sejumlah qanun. Khusus untuk kepentingan penegakan hukum pidana Islam (Jinayah), hingga tahun 2004 telah dibentuk lima qanun sebagai sumber hukum

${ }^{1}$ Anton Widyanto, Implementasi Fiqh In Concreto, Sebuah Reorientasi Metodologis Pelaksanaan Syariat Islam di NAD, Dinas Syariah Islam Provinsi, Banda Aceh, 2007, hlm.70.

${ }^{2}$ Di zaman kemerdekaan provinsi Aceh telah dua kali memperoleh hak istimewa dari pemerintah pusat yaitu sejak dikeluarkannya Keputusan Perdana Menteri Republik Indonesia No. I/MISSI/1959, dan menjadikan wilayah Aceh sebagai Daerah Istimewa. Keistimewaan tersebut meliputi bidang-bidang agama, adat dan pendidikan. Lihat: M. Kaoy Syah, Keistimewaan Aceh Dalam Lintasan Sejarah, Proses Pembentukan UU Nomor 44 Tahun 1999, dalam Azman Ismail, Syariat Islam di Nanggroe Aceh Darussalam, Dinas Syariat Islam Provinsi NAD, Banda Aceh, 2007, hlm. 105.

${ }^{3}$ Choiruddin Sobari, Kearifan Masyarakat Lokal Aceh Sebagai Potret Pelaksanaan Syariat Islam, dalam Syamsul Rijal, Dinamika Sosial Keagamaan Dalam Pelaksanaan Syariat Islam, Dinas Syariat Provinsi NAD, Banda Aceh, 2007, hlm. 88.

${ }^{4}$ Taslim H.M. Yasin, Pluralisme Agama di Wilayah Syari'at, dalam Syamsul Rijal, dkk., Dinamika Sosial Keagamaan Dalam Pelaksanaan Syariat Islam, Dinas Syariat Islam Provinsi NAD, Banda Aceh, 2007, hlm. 38.

${ }^{5}$ Secara harfiah, qanun (Arab) berarti undang-undang. Dalam konteks historis Aceh, lembaga pemerintahan dalam struktur Kerajaan Aceh Darussalam yang berwenang membuat qanun bermula sejak masa pemerintahan Sultan Iskandar Muda (1607-1636 M). Qanun dibuat atas saran dan prakarsa Putroe Phang (Putri Pahang), bernama asli Putri Kamaliyah, yang merupakan permaisuri Sultan Iskandar Muda, berasal dari Negeri Pahang Malaysia. Lihat: Muhammad Umar, Peradaban Aceh (Tamadun) II, Boebon Jaya, Banda Aceh, 2008, hlm. 73. 
materiil. Kelima qanun dimaksud adalah, (1) Qanun Nomor 11 Tahun 2002 tentang pelaksanaan syariat Islam bidang aqidah, ibadah dan syiar Islam; (2) Qanun Nomor 12 tahun 2003 tentang khamar (minuman keras) dan sejenisnya; (3) Qanun Nomor 13 Tahun 2003 tentang Maisir (judi); (4) Qanun Nomor 14 Tahun 2003 tentang Khalwat (mesum); dan (5) Qanun Nomor 7 Tahun 2004 tentang Pengelolaan Zakat. Hingga tahun 2010, kendatipun berbagai qanun tersebut telah mengalami revisi di Dewan Perwakilan Rakyat (DPR) Aceh, namun qanun yang telah direvisi belum memperoleh pengesahan Gubernur Nanggroe Aceh Darussalam (NAD).

Adanya kebebasan melaksanakan syariat Islam sebagai bagian dari otonomi khusus ini, menjadikan Provinsi Nanggroe Aceh Darussalam (NAD) sebagai wilayah yang memiliki keunikan dalam penegakan hukum. Provinsi ini menjadi sebuah laboratorium hukum yang sesungguhnya, bagaimana penegakan syari' at Islam dalam memberikan rasa keadilan kepada warga masyarakat di tanah air. Bagaimanapun hasil yang dicapai dalam penegakan syari'at Islam di Provinsi Nanggroe Aceh Darussalam (NAD) ini, menjadi contoh bagi daerah-daerah lain di Indonesia.

Sembilan tahun sejak berlakunya Undang-Undang Nomor 18 Tahun 2001 yang merupakan payung hukum penegakan syariat Islam di Provinsi Nanggroe Aceh Darussalam (NAD), hingga saat ini masih saja terdapat kontroversi mengenai penegakan syariat Islam di bumi Aceh. ${ }^{6}$ Kontroversi ini berkaitan dengan formalisasi penegakan syariat Islam dengan menjadikan hukuman ('uqubat) cambuk sebagai pidana pokok. Penggunaan dan penerapan pidana cambuk oleh kalangan tertentu dipandang sebagai suatu bentuk kekejaman, penyiksaan, bertentangan dengan rasa keadilan hukum dan merupakan pelanggaran hak asasi manusia di bumi Aceh. ${ }^{7}$

\section{Rumusan Masalah}

Bertitik tolak dari latar belakang di atas, maka masalah pokok yang dikaji di dalam tulisan ini adalah perihal bagaimana penerapan pidana cambuk dalam konteks penegakan syariat Islam di Provinsi Nanggroe Aceh Darussalam (NAD) dilihat dari sisi keadilan hukum dan hak asasi manusia.

\footnotetext{
${ }^{6}$ Kendatipun terdapat banyak kabupaten kota yang berusaha melakukan penegakan syariat Islam melalui pembentukan Perda bernuansa syariah, namun juga terdapat orang-orang yang alergi mendengarnya, sehingga seakan terjadi pro-kontra terhadap Perda bernuana syariah itu. Lihat: Muhammad Alim, Perda Bernuansa Syariah Dan Hubungannya Dengan Konstitusi, dalam Jurnal Hukum FH UII Vol. 17 No. 1 Januari 2010, hlm. 133.

7 ANTARA News Senin, 1 Pebruari 2010 23:17: Kontras: Hentikan Hukum Cambuk di Aceh, dalam bttp:/ / beta.antara.co.id/berital 1265041074 / kontras-hentikean-bukum-cambuk-di-aceh, diunduh Selasa 27 April 2010 pukul 11:30.
} 


\section{Tujuan Penelitian}

Penelitian ini bertujuan untuk mengetahui bagaimana penerapan pidana cambuk dalam konteks penegakan syariat Islam di Provinsi Nanggroe Aceh Darussalam (NAD) dilihat dari sisi keadilan hukum dan hak asasi manusia.

\section{Metode Penelitian}

Penelitian ini merupakan penelitian hukum empiris dengan menggunakan pendekatan nondoktrinal (socio legal research). ${ }^{8}$ Data penelitian berkaitan dengan pelaksanaan penegakan hukum pidana Islam di Provinsi Nanggroe Aceh Darussalam (NAD). Materi penelitian meliputi aturan hukum yang mendukung berlakunya hukum pidana Islam, mekanisme bekerjanya institusi-insitusi penegakan hukum, serta putusan peradilan syariah dalam perkara jinayah.

Pengumpulan data primer dilakukan melalui studi lapangan dengan melakukan wawancara mendalam dengan para informan yang dipilih secara purposif. ${ }^{9}$ Sementara itu, pengumpulan data sekunder dilakukan melalui studi dokumen. Analisis data dilakukan dengan menggunakan teknik analisis data kualitatif. Dalam hal ini, data deskriptif tentang pelaksanaan pidana cambuk dielaborasi dengan konsep-konsep dasar keadilan hukum dan hak asasi manusia, sehingga dapat diperoleh penjelasan yang konklusif bagaimana penjelasan ilmiah pemberlakuan pidana cambuk di Provinsi Nanggroe Aceh Darussalam (NAD) tersebut.

\section{Hasil Penelitian dan Pembahasan}

\section{Visi Dasar Penegakan Syariat Islam}

Pelaksanaan otonomi khusus yang meliputi kewenangan menegakkan syariat Islam di Provinsi Nanggroe Aceh Darussalam (NAD) telah ditindaklanjuti dengan pembuatan berbagai qanun. Penyusunan berbagai qanun dimaksud dilakukan dengan bertumpu pada garis-garis kebijakan yang rasional yang dituangkan di dalam

\footnotetext{
${ }^{8}$ Menurut Peter Mahmud Marzuki, penelitian ini kendatipun mengkaji hukum sebagai objeknya namun bukan merupakan penelitian hukum yang sesungguhnya melainkan penelitian sosial yang menempatkan hukum sebagai salah satu gejala sosial. Peter Mahmud Marzuki, Penelitian Hukum, Kencana Prenada Group, Jakarta, 2007, hlm. 87.

${ }^{9}$ Pola pemilihan sampel sesuai dengan tujuan penelitian. Deddy Mulyana, Metodologi Penelitian Kualitatif, Remaja Rosdakarya, Bandung, 2002, hlm. 187.
} 
Peraturan Daerah Nomor 5 Tahun 2000 sebagai Pelaksanaan Syariat Islam. Peraturan daerah ini merupakan pelaksanaan dari UU Nomor 44 Tahun 1999 tentang Penyelenggaraan Keistimewaan Propinsi Daerah Istimewa Aceh. Di dalam Perda tersebut ditetapkan bahwa syariat Islam yang ditulis dan diberlakukan di Aceh harus bersifat kaffah (menyeluruh, mencakup seluruh aspek kehidupan) yang ditegakkan di atas tiga prinsip utama: (1) berpegang kepada Al-qur'an dan Sunnah secara penuh; (2) melakukan pemahaman dan penalaran atas ketentuan Al-qur'an dan Sunnah tersebut berdasarkan metode ilmiah (memenuhi syarat dan dapat dipertanggungjawabkan) guna memenuhi kebutuhan masyarakat Aceh masa kini dalam bingkai Negara Kesatuan Republik Indonesia (NKRI); serta (3) berorientasi ke depan untuk mengantisipasi kebutuhan umat yang muncul karena pembangunan dan kemajuan di abad ke dua puluh satu miladiah atau kelima belas hijriyah. ${ }^{10}$

Keberhasilan pemerintah Provinsi Nanggroe Aceh Darussalam (NAD) dalam mempersiapkan sejumlah perangkat hukum berupa qanun sebagai payung hukum penegakan syariat Islam, merupakan langkah positif menuju keberhasilan penegakan syariat Islam ini. Lembaga yang oleh pemerintah Provinsi Nanggroe Aceh Darussalam (NAD) diberi wewenang mempersiapkan pelaksanaan syari'at Islam ini adalah Dinas Syariat Islam Provinsi dan Kabupaten/Kota di Provinsi Nanggroe Aceh Darussalam (NAD). Visi penegakan syariat Islam di Provinsi Nanggroe Aceh Darussalam (NAD) adalah "terwujudnya masyarakat Aceh yang sejahtera dan bermartabat sebagai hasil dari pelaksanaan syariat Islam secara kaffah". Visi ini kemudian dijabarkan lebih lanjut dalam rumusan misi, (1) menyebarluaskan pelaksanaan syariat Islam; (2) mempersiapkan, mensosialisasikan qanun dan perundang-undangan pelaksanaan syariat Islam; (3) mempersiapkan dan membina sumber daya manusia pelaksana dan pengawasan syariat Islam; (4) membina dan memantapkan kesadaran beragama masyarakat; dan (5) mewujudkan pengadilan yang jujur, adil, mengayomi, berwibawa serta murah, dan cepat. ${ }^{11}$

Selain pembentukan berbagai peraturan perundang-undangan di tingkat daerah Provinsi Nanggroe Aceh Darussalam (NAD), di tingkat pemerintah pusat juga telah dilakukan perubahan terhadap berbagai peraturan perundang-undangan yang mengatur kedudukan dan kewenangan berbagai lembaga penegak hukum. Dalam

\footnotetext{
${ }^{10}$ Al Yasa Abubakar, Kajian Undang-undang Pemerintahan Aceh dan Esay Tentang Perempuan, Perkawinan dan Perwalian Anak, Dinas Syariah Provinsi NAD, Banda Aceh, 2007, hlm. 17.

${ }^{11}$ Taslim H.M. Yasin, Pluralisme Agama di Wilayah Syari'at, dalam Syamsul Rijal, et. al, Dinamika Sosial Keagamaan Dalam Pelaksanaan Syariat Islam, Dinas Syariat Islam Provinsi NAD, Banda Aceh, 2007, hlm. 38.
} 
hal ini dapat disebut, Undang-Undang Nomor 2 Tahun 2002 tentang Kepolisian, Undang-Undang Nomor 4 Tahun 2004 tentang Pokok-Pokok Kekuasaan Kehakiman, Undang-Undang Nomor 16 Tahun 2004 tentang Kejaksaan. Selain itu juga terdapat Undang-Undang Nomor 16 Tahun 2006 tentang Pemerintahan Aceh. Di dalam Undang-undang yang disebut terakhir ini terdapat penetapan kedudukan dan fungsi lembaga wilayatul hisbah (WH) sebagai pengawas pelaksanaan syari'at dan melakukan penegakan hukum atas qanun-qanun penegakan syari'at Islam. ${ }^{12}$ Di masa depan, wilayatul hisbah ini diproyeksikan akan ditingkatkan perannya sebagai pelaksana fungsi penyidikan pada kasus-kasus pelanggaran qanun menggantikan kepolisian sebagai penyidik. ${ }^{13}$

\section{Ruang lingkup Kewenangan Mahkamah Syariah}

Dalam bekerjanya peradilan syariah Islam di Provinsi Nanggroe Aceh Darussalam (NAD), putusannya ditentukan oleh Mahkamah Syariah Kota atau Kabupaten untuk tingkat pertama, dan Mahkamah Syariah Provinsi untuk tingkat banding. Jika dilihat berdasarkan Undang-Undang Nomor 4 Tahun 2004 tentang Kekuasaan Kehakiman, peradilan syariah Islam memiliki keunikan yang berbeda dengan badan peradilan khusus lainnya. Hal ini disebabkan, peradilan syariah merupakan pengadilan khusus dalam lingkungan peradilan agama sepanjang kewenangannya menyangkut kewenangan peradilan agama, dan merupakan pengadilan khusus dalam lingkungan peradilan umum sepanjang kewenangannya menyangkut kewenangan peradilan umum. ${ }^{14}$

Mahkamah Syariah Provinsi bertugas dan berwenang memeriksa dan memutuskan perkara yang menjadi kewenangan Mahkamah Syariah dalam tingkat banding. Mahkamah Syariah Provinsi juga bertugas dan berwenang mengadili dalam tingkat pertama dan terakhir sengketa kewenangan antar Mahkamah Syariah di Provinsi Nanggroe Aceh Darussalam (NAD). Sementara itu, sengketa wewenang antara mahkamah syariah dan pengadilan dalam lingkungan peradilan lain menjadi wewenang Mahkamah Agung Republik Indonesia untuk tingkat pertama dan terakhir. Mahkamah Syariah untuk pengadilan tingkat kasasi dilakukan pada

\footnotetext{
${ }^{12}$ Pasal 244 dan 245 Undang-undang Nomor 16 Tahun 2006 tentang Pemerintahan Aceh.

${ }^{13}$ Qanun tentang peningkatan peran Wilayatul Hisbah hingga saat ini masih berada pada tingkat rancangan.

${ }^{14}$ Komisi Hukum Nasional, http://www/komisihukum.go.id/attach/NAD/doc diunduh Kamis, 01 Juni 2008 pukul 08:47:38.
} 
Mahkmah Agung Republik Indonesia. Kewenangan Mahkamah Syariah di Provinsi Nanggroe Aceh Darussalam (NAD) ini berlaku bagi pemeluk agama Islam, dan tidak berlaku bagi warga nonmuslim. ${ }^{15}$

Kewenangan Mahkamah Syariah sebagai peradilan syariat Islam diatur melalui qanun yakni Qanun Peradilan Syariat Islam No. 10 Tahun 2002. Qanun ini sekaligus merupakan peraturan pelaksanaan yang bersifat lex spesialis sesuai dengan UU Nomor 18 Tahun 2001 tentang Otonomi Khusus Provinsi Nanggroe Aceh Darussalam (NAD). ${ }^{16}$ Tugas pokok dan fungsi Mahkamah Syariah dibedakan menjadi dua bidang, yakni (1) bidang yustisial, dan (2) bidang nonyustisial. Dalam bidang yustisial, mahkamah bertugas dan berfungsi menerima, memeriksa, memutus dan menyelesaikan perkaraperkara antara orang-orang Islam di bidang al-ahwal al-syakhsiyah (hukum keluarga), muamalah (perdata) dan Jinayah (pidana). Perkara al-ahwal al-syakhshiyah meliputi masalah perkawinan, kewarisan, dan wasita. Bidang mua'amalah di antaranya meliputi masalah jual beli, utang piutang, qiradh (permodalan), bagi hasil, pinjammeminjam, perkongsian, wakilah, penyitaan, gadai, sewa-menyewa, dan perburuhan.

Perkara jinayah meliputi tiga jenis perkara, yaitu $h u d u d,{ }^{17}$ qishas, ${ }^{18}$ dan $t a^{\prime} z i r .{ }^{19}$ Hudud meliputi masalah zina dan menuduh berzina (qadhaf), mencuri dan merampok, minuman keras dan nafza, murtad. Dalam lingkup perbuatan mencuri dan merampok ini termasuk pula di dalamnya perbuatan korupsi. ${ }^{20}$ Qishash meliputi

\footnotetext{
${ }^{15}$ Komisi Hukum Nasional, http://www/komisihukum.go.id/attach/NAD/doc diunduh Kamis, 01 Juni 2008 pukul 08:47:38.

${ }^{16}$ http://www.solusihukum.com/kasus2.php?id=34 diunduh Kamis, 01 Juni 2008, pukul 08:44:56.

${ }^{17}$ Hudud adalah tindak pidana (jarimah) yang diancam dengan hukuman had. Menurut Wahbah Zuhayli, had adalah suatu ketentuan yang apabila dilanggar, maka pelakunya dihukum dengan hukuman yang telah ditentukan dalam al-Qur'an, tidak boleh ditambah dan dikurangi. Lihat: Misran, Dasar Yuridis Penentuan Ta'zir Oleh Penguasa, dalam Syahrizal, dkk., Dimensi Pemikiran Hukum Dalam Implementasi Syariat Islam di Aceh, Dinas Syariat Islam Provinsi NAD, Banda Aceh, 2007, hlm. 128,129.

${ }^{18}$ Menurut Muhammad Abdul Rasjid, qishash secara harfiah berarti 'melacak jejak musuh', yang merupakan hukum persamaan dalam Islam. Lihat: Muhammad Abdul Rasjid, Indeks Al Qur'an A - Z, Diglossia Media Group, Yogyakarta, 2007, hlm. 355. Sementara itu, menurut 'Abd al-Qadir 'Awdah, qishas adalah jarimah yang diancam dengan hukum yang setimpal atau sepadan dengan perbuatannya, yaitu dibunuh kalau perbuatannya membunuh, atau dianiaya kalau perbuatannya menganiaya. Dengan kata lain, qishash adalah ketentuan balasan setimpal yang dikenakan kepada pelaku jarimah menurut apa yang dilakukannya kepada orang lain. Qishash memiliki ketentuan yang sudah pasti, tertentu, tidak ada batas tertinggi danterendah, dan merupakan hak manusia (hak perorangan) dengan pengertian bahwa si korban atau walinya bisa menuntut diberlakukannya qishas kepada pelaku jarimah (berarti menjatuhkan qishash) atau memaafkan pekau jarimah (berarti menggugurkan qishas) sehingga hukuman menjadi hapus. Lihat: Misran, Dasar Yuridis Penentuan Ta’zir Oleh Penguasa, dalam Syahrizal, dkk., Op.Cit., hlm. 129.

${ }^{19}$ Menurut Sayyid Sabiq, ta'zir adalah hukuman yang bersifat edukatif yang ditentukan oleh hakim atau pemerintah atas pelaku jarimah yang hukumannya tidak ditentukan oleh syara' atau kepastian hukumnya belum ada. Lihat: Misran, Dasar Yuridis Penentuan Ta’zir Oleh Penguasa, dalam Syahrizal, dkk., Op.Cit., hlm. 137.

${ }^{20}$ Komisi Hukum Nasional, http://www.komisihukum.go.id/konten.php?nama=Opini\&op= detail opini\&id=60 diunduh Selasa 03 Juni 2008, pukul 12:45:15.
} 
masalah pembunuhan dan penganiayaan. Ta'zir meliputi masalah judi, penipuan, pemalsuan, khalwat serta meninggalkan shalat dan puasa. Sementara itu, tugas dan fungsi dalam bidang nonyustisial meliputi pengawasan jalannya Mahkamah Syari'ah, hisab dan rukyat, menyaksikan pengangkatan gubernur/wakil gubernur dan bupati/ wakil bupati. Mahkamah Syariah juga berwenang memberikan nasihat dan pertimbangan hukum bagi lembaga pemerintah yang memerlukan.

Ruang lingkup kewenangan Mahkamah Syariah dalam mengadili perkara pidana adalah terbatas, sebab tidak semua kasus pidana ditangani oleh Mahkamah Syariah. Mahkamah Syariah hanya menangani kasus-kasus pidana yang sudah diatur dengan qanun, yakni yang terdapat dalam lima qanun syariah tersebut di atas. ${ }^{21}$ Adanya kewenangan Mahkamah Syariah memeriksa perkara pidana, tidak mengurangi kewenangan badan peradilan umum, sebab kewenangan Mahkamah Syariah yang diatur oleh qanun merupakan hasil kriminalisasi terhadap perbuatanperbuatan yang tidak diatur Kitab Undang-Undang Hukum Pidana (KUHP).

Dalam proses penegakan hukum pidana Islam (jinayah), sistem peradilan syariah berawal dari berfungsinya wilayatul hisbah (WH) sebagai ujung tombak yang berwenang menerima laporan terjadinya kasus pelanggaran qanun syariah. Jika berdasarkan pertimbangan, suatu kasus layak diajukan ke Mahkamah Syariah, maka wilayatul hisbah (WH) akan melanjutkan perkara kepada kepolisian yang berwenang melakukan penyidikan disertai penyerahan alat bukti dan tersangka.

Dalam hal kepolisian memandang semua syarat objektif (tindak pidana) dan subjektif (kesalahan tersangka) terpenuhi, maka Berita Acara Pemeriksaan (BAP) akan diserahkan kepada kejaksaan disertai alat bukti dan tersangka. Selanjutnya kejaksaan menyusun surat dakwaan dan melimpahkan ke Mahkamah Syariah Kota/ Kabupaten. Seluruh rangkaian proses beracara dan pemeriksaan di sidang pengadilan dijalankan berdasarkan Undang-Undang Nomor 8 Tahun 1981 tentang Kitab Undang-undang Hukum Acara Pidana (KUHAP) ditambah berbagai peraturan pelaksanaan terkait dengan penanganan perkara pelanggaran syariah.

\section{Asas Personalitas Keislaman dan Penundukan Diri}

Sebagai lembaga yang menyelenggarakan peradilan syariat Islam, kewenangan Mahkamah Syariah dilaksanakan berdasarkan Syariat Islam dalam bingkai sistem

\footnotetext{
${ }^{21}$ http://www.solusihukum.com/kasus2.php?id=34 diunduh Kamis, 01 Juni 2008, pukul 08:44:56.
} 
hukum nasional. Kewenangan tersebut diatur lebih lanjut dengan Qanun Provinsi Nanggroe Aceh Darussalam (NAD) dan diberlakukan bagi pemeluk agama Islam. Hal ini secara tegas ditentukan dalam Pasal 25 Undang-Undang Nomor 18 Tahun 2001. Ini berarti bahwa asas yang dianut adalah asas personalitas keislaman, di samping asas teritorial. Sebagai realisasi dari ketentuan tersebut di atas, Pemerintah Provinsi Nanggroe Aceh Darussalam (NAD) telah mengeluarkan Qanun Nomor 10 Tahun 2002 tentang Peradilan Syariat Islam yang disahkan pada 14 Oktober 2002. Qanun tersebut selain mengatur kewenangan Mahkamah Syariyah, juga menyangkut susunan organisasi, pembinaan, hukum materil dan hukum formil yang akan digunakan serta hal-hal lainnya. Berdasarkan ketentuan Pasal 2 ayat (3) Qanun tersebut, Mahkamah Syariyah merupakan pengembangan dari pengadilan agama yang telah ada sebelumnya. ${ }^{22}$

Kewenangan Mahkamah Syariah baik di tingkat Kota/Kabupaten, maupun di tingkat provinsi, bertumpu pada berlakunya asas personalitas keislaman. Artinya Nanggroe Aceh Darussalam (NAD), namun dalam mengadili perkara pelanggaran syariat Islam, Mahkamah Syariah hanya berwenang mengadili orang yang beragama Islam (muslim) dan tidak berwenang mengadili seseorang yang tidak beragama Islam (nonmuslim). Berlakunya asas personalitas keislaman ini membawa konsekuensi, bahwa pelaku pelanggaran syariat Islam yang tidak beragama Islam tidak diadili di Mahkamah Syariah melainkan di pengadilan negeri. Dengan adanya batasan kewenangan demikian itu, maka suatu perkara yang dilakukan oleh dua orang atau lebih yang berbeda agama, masing-masing diperiksa atau diadili oleh badan peradilan yang berbeda.

Sejak berlakunya aturan hukum pidana Islam di Provinsi Nanggroe Aceh Darussalam (NAD), terdapat beberapa kasus pelanggaran syariat Islam berupa tindak pidana (jarimah) yang dilakukan secara bersama-sama antara orang yang beragama Islam dan orang yang tidak beragama Islam. Kasus-kasus yang dilakukan secara bersama-sama terutama kasus perdagangan minuman keras (khamar) dan perjudian (maisir). Dalam proses penyidikan di Kepolisian, terdapat beberapa tersangka yang nonmuslim bermaksud mengikuti proses peradilan di Mahkamah Syariah. Para tersangka secara sendiri-sendiri dan pribadi dengan bantuan penasihat hukumnya

${ }^{22}$ Armia Ibrahim, 2009, Peraturan Perundang-Undangan Tentang Pelaksanaan Syariat Islam Di Aceh, dalam http://www.mahkamahsyariahaceh.go.id/images/stories/ food/data/peraturan/pp tentang_pelak-sanaan_si.pdf diunduh Rabu, 17 Februari 2010 19:35. 
menyusun surat pernyataan penundukan diri. Surat pernyataan penundukan diri memuat permohonan kepada Ketua Mahkamah Syariah agar diperkenankan menjalani pemeriksaan perkaranya di Mahkamah Syariah dan secara sukarela menerima semua konsekuensi hukum atas penundukan diri tersebut, termasuk di dalamnya bersedia menjalani eksekusi pidana cambuk sebagaimana mestinya.

Berdasarkan pertimbangan normatif, batasan kewenangan mengadili Mahkamah Syariah, maka pada kasus-kasus penundukan diri ini majelis hakim memutuskan menolak semua pemohonan penundukan diri dari para tersangka yang nonmuslim. Dengan demikian para tersangka nonmuslim wajib menjalani persidangan perkaranya di pengadilan negeri. Kasus-kasus penundukan diri dari para tersangka nonmuslim terjadi berulangkali pada tahun-tahun awal berlakunya hukum pidana Islam (jinayah) di Provinsi Nanggroe Aceh Darussalam (NAD).

Fenomena upaya penundukan diri secara sukarela ini menarik dikaji, perihal pertimbangan yang memotivasi para tersangka yang nonmuslim untuk mengajukan permohonan penundukan diri. Dokumen-dokumen pernyataan penundukan diri yang disertakan di dalam berkas perkara dan wawancara dengan beberapa responden, dapat diketahui motivasi yang mendasari tindakan penundukan diri tersebut. Pada dasarnya keinginan para tersangka menundukkan diri secara sukarela pada kewenangan mahkamah syariah terkait pada pertimbangan praktis dalam aspek rasa keadilan secara sosial, ekonomi dan hak asasi manusia.

Berdasarkan pemikiran para tersangka, bilamana mereka menjalani persidangan perkara di pengadilan negeri, maka dapat diduga putusan hakim akan berupa pidana kurungan yang berlangsung selama beberapa bulan. Masa menjalani pidana kurungan selama beberapa bulan ini akan sangat memberatkan bagi keluarganya, karena sebagai tulang punggung ekonomi keluarga dia tidak bisa bekerja mencari nafkah. Oleh karena mereka berkeinginan segera terbebas dari masalah hukum ini, para tersangka beranggapan seandainya pidana kurungan itu diganti dengan pidana cambuk, maka proses eksekusi akan berjalan singkat dan dengan demikian dia bisa kembali kepada keluarga dan bekerja mencari nafkah. Berdasarkan rasa sakit yang mungkin dirasakan karena menjalani eksekusi pidana cambuk, para tersangka berkeyakinan bahwa eksekusi pidana cambuk tidak menyebabkan rasa sakit yang berat dan tidak akan menimbulkan cedera. Dengan demikian dalam pandangan mereka pelaku pelanggaran syariat, pelaksanaan pidana cambuk sesungguhnya bukanlah merupakan tindakan penyiksaan. Dibandingkan dengan penderitaan 
anggota keluarga secara sosial dan ekonomi yang harus ditanggungkan selama beberapa bulan selama menjalani pidana kurungan, maka penderitaan yang ditanggungkan selama menjalani pidana kurungan jelas jauh lebih berat baik bagi siterpidana maupun anggota keluarganya. Dengan demikian, penderitaan yang dikenakan melalui pidana kurungan lebih tepat dipandang sebagai penyiksaan dalam arti yang sesungguhnya dibandingkan dengan pidana cambuk.

\section{Penerapan Cambuk dalam Perspektif Keadilan Hukum dan HAM}

Pidana cambuk merupakan salah satu jenis pidana yang diancamkan terhadap pelaku tindak pidana (jarimah) sebagaimana terdapat di dalam berbagai qanun. Selain pidana cambuk, pidana dalam bentuk lain yang juga diancamkan di dalam qanun adalah pidana kurungan dan pidana denda. Di samping itu juga dimungkinkan adanya penjatuhan pidana administratif. Pidana administratif berupa pencabutan izin usaha diancamkan kepada perusahan angkutan penumpang yang tidak memberikan fasilitas kepada penumpang untuk melaksanakan ibadah sebagaimana mestinya, ${ }^{23}$ atau menyediakan fasilitas/peluang untuk tidak berpuasa bagi orang yang wajib berpuasa pada bulan Ramadhan, ${ }^{24}$ atau turut serta/membantu memproduksi, menyediakan, menjual, memasukkan, mengedarkan, mengangkut, menyimpan, menimbun, memperdagangkan, menghadiahkan, mempromosikan minuman khamar dan sejenisnya. ${ }^{25}$

Dalam mempertimbangkan penjatuhan pidana kepada pelaku pelanggaran qanun (jarimah), hakim tidak selalu menjatuhkan pidana cambuk. Kecuali pada jarimah hudud, yang ancaman pidananya bersifat tunggal, dalam hal $t a^{\prime} z i r$, hakim dapat bergerak dalam batas-batas kewenangan hakim sejalan dengan batas maksimal dan minimal hukuman $t a^{\prime} z i r$ yang diancamkan. Dalam hal jarimah maisir (judi), sebagaimana ditetapkan dalam Pasal 23 juncto Pasal 51 Qanun Nomor 13 Tahun 2003 memberikan ancaman hukuman cambuk maksimal 12 (dua belas) kali dan minimal 6 (enam) kali.

Dalam hal hakim menjatuhkan pidana cambuk, eksekusi dilaksanakan di bawah koordinasi dan tanggung jawab jaksa penuntut umum. Secara teknis operasional, eksekusi dilaksanakan oleh petugas dari Dinas Syariah Kota/Kabupaten setempat.

\footnotetext{
${ }^{23}$ Pasal 21 juncto Pasal 9 ayat (3) Qanun Nomor 11 Tahun 2002 tentang pelaksanaan syariat Islam bidang aqidah, ibadah dan syiar Islam.

${ }^{24}$ Pasal 21 juncto Pasal 10 ayat (1) Qanun Nomor 11 Tahun 2002 tentang pelaksanaan syariat Islam bidang aqidah, ibadah dan syiar Islam.

${ }^{25}$ Pasal 27 juncto Pasal 6 ayat (2) Qanun Nomor 12 Tahun 2003 tentang Khamar (Minuman Keras).
} 
Petugas pelaksana pencambukan berasal dari wilayatul hisbah kota/kabupaten. Biaya operasional eksekusi pidana cambuk bersumber dari Pemerintah Kota/ Kabupaten melalui Dinas Syariah. Karena pertimbangan efisiensi, eksekusi biasanya dilakukan terhadap beberapa terpidana secara berurutan pada hari yang sama.

Sehubungan dengan tidak adanya penahanan terhadap terpidana cambuk, maka seseorang terpidana cambuk tetap hidup bebas kendatipun pidana yang telah diputuskan hakim belum dieksekusi. Manakala proses eksekusi akan dilaksanakan pada hari dan tanggal tertentu, jaksa penuntut umum akan mengirimkan surat panggilan untuk hadir di tempat dan waktu yang telah ditentukan. Dengan demikian, kehadiran terpidana cambuk untuk menjalani eksekusi bersifat sukarela, atas dasar kesadaran sendiri. Kejaksaan tidak pernah berusaha melakukan penjemputan paksa untuk kepentingan eksekusi ini. Pada umumnya kehadiran para terpidana, di samping atas kemauan sendiri, juga karena disemangati oleh anggota keluarga atau kerabat dekat.

Tidak semua terpidana cambuk memiliki kerelaan hati yang cukup untuk menjalani pidana cambuk yang telah dijatuhkan hakim. Dalam berbagai kasus pada hari dan tanggal yang telah ditetapkan, terpidana yang telah dijatuhi pidana cambuk sebanyak 40 (empat puluh) kali, ternyata tidak hadir karena melarikan diri dan tidak diketahui lagi keberadaannya. Dengan demikian, eksekusi pidana cambuk terhadap terpidana yang melarikan diri tidak dapat dilaksanakan. Kasus-kasus terpidana yang melarikan diri dari eksekusi pidana cambuk terjadi berulang kali, khususnya pada kasus-kasus tindak pidana perdagangan minuman keras. Beberapa informan mengungkapkan bahwa kasus-kasus terpidana cambuk melarikan diri dari eksekusi disebabkan adanya provokasi dari bandar-bandar perdagangan minuman keras yang pada umumnya adalah oknum-oknum anggota militer.

Proses eksekusi pidana cambuk dilakukan dengan memperhatikan seksama aspek-aspek keadilan, keselamatan dan kesehatan dari terpidana. Hal ini berarti eksekusi pidana cambuk tidak dilakukan secara semena-mena. Berdasarkan Peraturan Gubernur Nomor 10 Tahun 2005 tentang Petunjuk Teknis Pelaksanaan Uqubat Cambuk, pelaksanaan pidana (uqubat) cambuk dilaksanakan dengan berpedoman pada sejumlah ketentuan. Beberapa ketentuan yang menjadi pedoman pelaksanaan pidana cambuk, yakni: (a) Pencambukan dilakukan oleh wilayatul hisbah (WH); (b) Di tempat yang dapat disaksikan orang ramai, dihadiri Jaksa dan dokter yang ditunjuk Departemen Kesehatan; (c) Pencambukan dilakukan ke seluruh badan, kecuali kepala, muka, leher, dada dan kemaluan; (d) Kadar cambukan tidak 
sampai melukai; (e) Terhukum laki-laki dicambuk dalam posisi berdiri tanpa diikat; (f) Terhukum wanita dicambuk dalam posisi duduk dan ditutup kain di atasnya; (g) Wanita hamil dicambuk 60 hari setelah melahirkan; (h) Bila membahayakan terhukum selama dicambuk berdasarkan pendapat dokter, maka sisa cambukan ditunda hingga waktu yang memungkinkan.

Jika disimak secara seksama prosedur pelaksanaan hukuman cambuk seperti di atas, terlihat dengan jelas bahwa prosedur standar tersebut telah mempertimbangkan dengan cermat segi-segi keadilan hukum dan hak asasi manusia. Penyerahan kewenangan eksekusi kepada petugas wilayatul hisbah di bawah koordinasi kejaksaan menunjukkan penghormatan pada legalitas kewenangan eksekusi serta kecakapan dalam melaksanakan pencambukan. Pelaksanaan eksekusi di depan publik menunjukkan adanya motif filosofis untuk mempermalukan pelaku atas perbuatan pelanggaran hukum yang dilakukannya, dan dengan kesediaannya menjalani eksekusi hukuman memungkinkannya memperoleh jalan terhormat baginya untuk berintegrasi kembali ke dalam masyarakat tanpa kekhawatiran adanya stigma kriminal. ${ }^{26}$ Proses ini tetap disertai dengan kehadiran tenaga medis, yang menunjukkan perhatian pada aspek kesehatan serta keselamatan jiwa dan raga terpidana.

Intensitas eksekusi pidana cambuk pada dasarnya relatif tidak berat. Pengertian intensitas eksekusi di sini adalah penggunaan tenaga fisik dari pelaku pencambukan (algojo) yang tidak maksimal. Pola eksekusi demikian ini juga merupakan bagian dari kebijakan penegakan syariat Islam di bumi Aceh. Kebijakan penegakan hukum pidana Islam (jinayah) diwarnai oleh pertimbangan perlunya upaya dan proses sosialisasi secara luas perihal sifat keadilan dan kemanfaatan dari syariat Islam, sebagai bagian dari sarana untuk mewujudkan citra syariat Islam yang rahmatan lil'alamin.

Pembatasan daerah sasaran pencambukan pada badan terpidana menunjukkan penghormatan pada kehidupan masa depan terpidana. Pukulan cambuk diharapkan hanya memberikan rasa sakit fisik yang bersifat sementara dan tidak menimbulkan cedera permanen, terutama pada bagian-bagian tubuh yang bersifat terbuka. Efek pukulan cambuk memang lebih ditekankan pada segi-segi psikis atau kejiwaan si terpidana berupa rasa jera dan komitmen untuk memperbaiki diri agar mampu mengendalikan diri dan tidak melakukan pelanggaran hukum lagi di kemudian hari.

${ }^{26}$ Secara konseptual hal ini sejalan dengan konstruksi filosofis teori Reintegrative Shaming sebagaimana dikemukakan oleh John Braithwhite, Crime, Shame and Reintegration, Cambridge University Press, Cambridge, 1989, hlm. 65. 
Pembedaan perlakuan terhadap terpidana laki-laki dan terpidana perempuan, menegaskan penghormatan pada kondisi yang berbeda di antara keduanya. Dalam hal ini perlakuan yang sama antara terpidana laki-laki dan terpidana perempuan justru akan menimbulkan ketidakadilan yang sangat mendasar. Demikian halnya denganklausul yang diberlakukan terhadap terpidana perempuan yang sedang hamil. Penundaan eksekusi pidana cambuk untuk terpidana perempuan yang sedang hamil, mencerminkan penghormatan pada nilai-nilai keadilan hukum dan hak asasi manusia secara keseluruhan.

Klausul yang memungkinkan penghentian pelaksanaan pencambukan bilamana terjadi kondisi emergensi pada diri terpidana, juga menunjukkan penghormatan yang tinggi pada integritas kemanusiaan si terpidana. Semua ketentuan prosedur eksekusi pidana cambuk sebagaimana tersebut di atas memperlihatkan konsistensi konsep dan filosofi pidana cambuk sebagai instrumen penegakan hukum guna mewujudkan kemaslahatan (kebaikan) dan mencegah kemudharatan (keburukan) baik bagi diri si terpidana maupun masyarakat secara keseluruhan,

Oleh karena itu, pada hakikatnya penjatuhan dan pelaksanaan pidana cambuk bagi para pelaku pelanggaran syariat Islam telah sejalan dengan nilai keadilan hukum baik dalam hubungan manusia dengan Tuhan Sang Pencipta Alam Semesta (hablun min Allah), maupun dalam hubungan sesama manusia (hablun min annas). Hal ini disebabkan hukuman cambuk merupakan sesuatu yang telah melekat erat dengan ketentuan syariat Islam itu sendiri.

Dilihat dari sisi pencapaian tujuan pemidanaan dengan menggunakan pidana cambuk, terlihat bahwa angka recidive atau pengulangan tindak pidana pada terpidana yang menjalani eksekusi pidana cambuk sangat berhasil. Indikator keberhasilan ini adalah tidak adanya kasus pengulangan tindak pidana yang dilakukan mantan terpidana pidana cambuk. Keadaan sangat kontras jika dibandingkan dengan para terpidana pidana kurungan ataupun pidana denda. Pada berbagai jenis pelanggaran pidana syariat Islam yang pelakunya dijatuhi pidana kurungan atau denda, ternyata angka recidive ini sangat tinggi. Dilihat dari sisi ini, nampak bahwa keberhasilan penegakan hukum untuk mewujudkan kebaikan bagi si terpidana justru lebih berhasil pada kasus-kasus yang pelakunya dikenai pidana cambuk.

\section{Diskriminasi Penegakan Hukum dan Ketidakadilan}

Tujuan penegakan syariat Islam dengan menerapkan pidana cambuk, menghadapi berbagai tantangan. Salah satu bentuk tantangan ini berkaitan dengan 
gencarnya upaya segelintir pihak yang mencoba melakukan provokasi dengan membuat pernyataan-pernyataan yang menunjukkan ketidaksetujuan terhadap penerapan hukuman cambuk, bahkan penegakan syariat Islam secara umum.

Pihak yang secara tegas menyatakan penolakan terhadap penerapan pidana cambuk di Provinsi Nanggroe Aceh Darussalam (NAD) adalah Komisi untuk Orang Hilang dan Tindak Kekerasan (Kontras) baik di Aceh maupun di Jakarta. Kelompok ini mengajukan desakan penghapusan pidana cambuk dengan alasan hukuman cambuk melanggar prinsip-prinsip hak asasi manusia. Koordinator KontraS Aceh Hendra Fadil adalah tokoh sentral yang mengajukan desakan penghentian hukuman cambuk dengan pertimbangan hukuman cambuk digolongkan pelanggaran hak asasi manusia secara sistematis. Desakan juga meliputi perlunya revisi ketentuan pemidanaan dalam hukum syariah ke bentuk lain yang tidak bertentangan dengan instrumen hak asasi manusia dan diterima oleh komunitas internasional. ${ }^{27}$

Dalam konteks ini layak diapresiasi tanggapan Kepala Biro Hukum dan Humas Pemerintah Aceh Makmur Ibrahim. Menurut Ibrahim, ketentuan mengenai hukuman cambuk yang berlaku di Aceh tertuang di dalam qanun. Proses pembuatan qanun telah melibatkan semua unsur yang berkompeten termasuk Mahkamah Agung. Dengan demikian penghentian hukuman cambuk hanya dimungkinkan bilamana telah melewati judicial review ke Mahkamah Agung, atau legislative review di Dewan Perwakilan Rakyat, dan bisa juga melalui executive review..$^{28}$ Pengajuan uji materiil itu hanya dimungkinkan bilamana ada desakan yang sangat besar dari masyarakat Aceh. Sejauh ini desakan penghentian hukuman cambuk hanya datang dari KontraS. ${ }^{29}$

Sikap dan tanggapan yang juga layak diapresiasi berasal dari Majelis Permusyawaratan Ulama (MPU) Provinsi Nanggroe Aceh Darussalam (NAD). Menurut Ketua Majelis Permusyawaratan Ulama (MPU) Aceh Muslim Ibrahim, penerapan hukuman cambuk merupakan sesuatu yang dibenarkan oleh agama Islam dan disetujui oleh Mahkamah Agung Indonesia. Oleh karena itu tidak ada alasan untuk memandang hukuman cambuk bertentangan dengan HAM. Berdasarkan hasil

\footnotetext{
${ }^{27}$ ANTARA News Senin, 1 Pebruari 2010 23:17: Kontras: Hentikan Hukum Cambuk di Aceh, dalam bttp:/ / beta.antara.co.id/berita/ 1265041074 / kontras-hentikan-bukum-cambuk-di-aceh, diunduh Selasa 27 April 2010 pukul 11:30.

${ }^{28}$ Pendapat senada juga dikemukakan oleh Rifyal Ka’bah, hakim agung pada Mahkamah Agung RI, bahwa dalam hal terapat pihak yang keberatan terhadap pemberlakuan perda bernuansa syariah, yang bersangkutan dapat mengajukan permohonan pengujian, judicial review, ke Mahkamah Agung. Lihat Muhammad Alim, "Perda Bernuansa Syariah Dan Hubungannya Dengan Konstitusi”, dalam Jurnal Hukum FH UII Vol. 17 No. 1 Januari 2010, hlm.136.

${ }_{29}$ Tempo Interaktif.com, Selasa, 02 Februari 2010, 12:10 WIB: Pemerintah Aceh Tak Berwenang Hentikan Hukum Cambuk, dalam http://www.tempointerkatif.com/hg/nusa/2010/02/02/brk;20100202-02.
} 
diskusi Majelis Permusyawaratan Ulama (MPU) Aceh dengan para ahli di bidang Hak Asasi Manusia (HAM), termasuk seorang warga negara Jerman yang ikut menyusun konvensi tentang Hak Asasi Manusia (HAM) di Persatuan Bangsa-Bangsa $(\mathrm{PBB})$, yang memuat salah satu item bahwa suatu ketentuan yang disepakati oleh komunitas masyarakat secara bersama-sama dengan prosesur tertentu seperti rapat musyawarah, diperoleh kesimpulan bahwa qanun tidak melanggar Hak Asasi Manusia (HAM). ${ }^{30}$

Bertitik tolak pada latar belakang sosial dan sejarah serta secara teknis adanya proses musyawarah yang mendahului penetapan diberlakukannya syariat Islam di seluruh wilayah Provinsi Nanggroe Aceh Darussalam (NAD), maka dapat disimpulkan bahwa penegakan syariat Islam pada umumnya dan penerapan pidana cambuk tidaklah bertentangan dengan nilai keadilan hukum dan hak asasi manusia. Namun demikian, terkait dengan keterbatasan kemampuan manusia dalam melakukan mobilisasi bekerjanya hukum, memang telah terjadi praktik penegakan hukum yang bersifat "tebang pilih". ${ }^{31}$ Penegakan hukum secara diskriminatif terjadi manakala aparat penegak hukum bertindak represif terhadap pelaku pelanggaran hukum dari kelompok tertentu tetapi bersifat permisif terhadap pelaku pelanggaran hukum dari kelompok lain. Dalam hal penerapan hukuman cambuk, aparat penegak hukum berlaku keras terhadap pelaku pelanggaran yang berlatar belakang sosial politik dan ekonomi yang lemah, sebaliknya aparat penegak hukum menutup mata terhadap para pelaku pelanggaran yang berlatar belakang sosial politik dan ekonomi tinggi.

Dalam hal praktik penegakan hukum bersifat tebang pilih berlangsung secara massif dan terbuka, akan mendorong timbulnya ketidakpuasan dan sikap apatis di dalam masyarakat. Perasaan kecewa, sakit hati dan semacamnya, sesungguhnya tidak bersumber pada substansi syariat Islam ataupun pidana cambuk yang dikenakan, melainkan karena mengetahui bahwa pengenaan pidana cambuk itu hanya berlaku pada warga masyarakat biasa, warga sipil yang sangat terbatas secara sosial politik

\footnotetext{
${ }^{30}$ MPU Aceh Angkat Bicara Terhadap Permintaan Penghapusan Hukuman Cambuk, dalam http:// humasaceh.info/hukum-a-kriminal/hukum/758-mpu-aceh-angkat-bicara-terhadap-permintaan-penghapusanhukuman-cambuk.html, diunduh Senin April 2010 pukul 11:46:05.

${ }^{31}$ Praktik penegakan hukum bersifaf "tebang pilih" lebih dikenal sebagai penegakan hukum secara selektif (selective enforcement) atau diskriminatif (discrimination) merupakan ekses dari bekerjanya hukum dalam struktur kekuasaan yang modern atau kompleks. William J. Chamblis \& Robert B. Seidman dalam Satjipto Rahardjo, Penegakan Hukum Suatu Tinjauan Sosiologis, Yogyakarta, Genta Publishing, 2009, hlm. 67; Bryan A. Garner, Black's Law Dictionary (Seventh Edition), Minn - St. Paul, West Group, 1999, hlm. 479, 1363.
} 
dan ekonomi. Sementara itu, para pelaku pelanggaran yang memiliki status sosial politik dan ekonomi baik seperti pejabat dan anggota polisi atau militer justru luput dari jangkauan hukum. Hal inilah yang dirasakan oleh para terpidana cambuk sebagai bentuk diskriminasi dan ketidakadilan hukum.

Penegakan hukum yang bersifat tebang pilih dan oleh karena itu menimbulkan ketidakadilan jelas sangat membahayakan upaya pencapaian penegakan syariat Islam. Manakala apatisme menjadi sikap yang meluas di dalam masyarakat, maka tujuan pemberlakuan syariat Islam di bumi serambi Mekkah yakni terwujudnya masyarakat Aceh yang adil dan makmur di bawah naungan syariat Islam menjadi semakin sulit dicapai. Keadaan ini merupakan isyarat bagi semua pemegang peran dalam proses penegakan syariat Islam di Provinsi Nanggroe Aceh Darussalam (NAD) untuk berusaha secara sungguh-sungguh mengupayakan penegakan syariat Islam secara lebih berkeadilan. Tanpa adanya tindakan antisipatif, penegakan syariat Islam di serambi Mekah akan mengalami kegagalan.

\section{Penutup}

Penelitian ini dapat disimpulkan, pertama, kewenangan Mahkamah Syariah mengadili perkara pidana pelanggaran syariat Islam tidak mengurangi kewenangan Pengadilan Negeri. Hal ini dikarenakan kewenangan Mahkamah Syariah terbatas pada perbuatan-perbuatan yang dikriminalisasikan melalui qanun (peraturan daerah). Kedua, kewenangan Mahkamah Syariah memeriksa perkara pelanggaran syariat Islam didasarkan pada asas teritorialitas dan asas personalitas keislaman. Asas teritorialitas menentukan bahwa syariat Islam yang diatur di dalam qanun berlaku terbatas dalam wilayah Provinsi Nanggroe Aceh Darussalam (NAD). Asas personalitas keislaman menentukan bahwa pemberlakuan syariat Islam di Provinsi Nanggroe Aceh Darussalam (NAD) terbatas pada orang-orang yang beragama Islam.

Ketiga, pemberlakuan syariat Islam di Provinsi Nanggroe Aceh Darussalam (NAD) adalah sejalan dengan realitas sosiologis dan kesejarahan daerah dan masyarakat Aceh. Sejarah sosial masyarakat Aceh memperlihatkan bahwa masyarakat Aceh telah menjalankan syariat Islam sejak lama, sehingga dikenal sebagai bumi serambi Makkah.

Keempat, kesesuaian ide-ide keadilan syariat Islam dengan prinsip-prinsip dasar keadilan hukum dan juga hak asasi manusia, dapat dilihat dari kasus-kasus upaya 
penundukan diri secara sukarela para tersangka pelaku tindak pidana pelanggaran qanun yang merupakan warga nonmuslim. Kendatipun semua permohonan penundukan diri secara sukarela dari pera tersangka nonmuslim ditolak oleh majelis hakim, namun motivasi dasar yang melandasi tindak mereka mengajukan permohonan penundukan diri merupakan sesuatu yang layak dihargai.

Kelima, ketidakadilan dalam pemberlakuan syariat Islam khususnya dalam penjatuhan pidana cambuk tidaklah bersumber dari substansi aturan hukum dan pidana cambuk yang dijatuhkan kepada pelaku pelanggaran syariat Islam, melainkan justru timbul dan dirasakan oleh warga masyarakat bersumber dari proses penegakan hukum yang bersifat diskriminatif. Petugas penegakan syariat Islam baru sebatas mampu menangkap dan memproses pelaku pelanggaran syariat dari kalangan rakyat kecil tetapi tidak mampu menjangkau pelaku pelanggaran syariat Islam dari kalangan pejabat dan pengusaha.

\section{Daftar Pustaka}

Abubakar, Al Yasa', Kajian Undang-undang Pemerintahan Aceh dan Esay Tentang Perempuan, Perkawinan dan Perwalian Anak, Dinas Syariah Provinsi NAD, Banda Aceh, 2007.

Abdul Rasjid, Muhammad, Indeks Al Qur'an A - Z, Diglossia Media Group, Yogyakarta, 2007.

Alim, Muhammad, "Perda Bernuansa Syariah Dan Hubungannya Dengan Konstitusi", dalam Jurnal Hukum FH UII Vol. 17 No. 1 Januari 2010.

Braithwhite, John, Crime, Shame and Reintegration, Cambridge University Press, Cambridge, 1989.

Garner, Bryan A., Black's Law Dictionary (Seventh Edition), Minn - St. Paul, Wet Group, 1999.

Ismail, Azman, Syariat Islam di Nanggroe Aceh Darussalam, Dinas Syariat Islam Provinsi NAD, Banda Aceh, 2007.

Mahmud Marzuki, Peter, Penelitian Hukum, Kencana Prenada Group, Jakarta, 2007.

Mulyana, Deddy, Metodologi Penelitian Kualitatif, Remaja Rosdakarya, Bandung, 2002.

Rahardjo, Satjipto, Penegakan Hukum Suatu Tinjauan Sosiologis, Genta Publishing, Yogyakarta, 2009.

Rijal, Syamsul, et. al, Dinamika Sosial Keagamaan Dalam Pelaksanaan Syariat Islam, Dinas Syariat Islam Provinsi NAD, Banda Aceh, 2007.

Syahrizal, et. al, Dimensi Pemikiran Hukum Dalam Implementasi Syariat Islam di Aceh, Dinas Syariat Islam Provinsi NAD, Banda Aceh, 2007. 
Umar, Muhammad, Peradaban Aceh (Tamadun) II, Boebon Jaya, Banda Aceh, 2008.

Widyanto, Implementasi Figh In Concreto, Sebuah Reorientasi Metodologis Pelaksanaan Syariat Islam di NAD, Dinas Syariah Islam Provinsi, Banda Aceh, 2007.

http://www.solusihukum.com/kasus2.php?id=34 diunduh Kamis, 01 Juni 2006, pukul 08:44:56.

Komisi Hukum Nasional, http://www.komisihukum.go.id/konten.php?nama= Opini \&op= detail opini\&id=60 diunduh Selasa 03 Juni 2008, pukul 12:45:15.

Undang-Undang No. 44 Tahun 1999 tentang Penyelenggaraan Keistimewaan propinsi Daerah Istimewa Aceh.

Undang-Undang Nomor 2 Tahun 2002 tentang Kepolisian.

Undang-Undang Nomor 4 Tahun 2004 tentang Pokok-pokok Kekuasaan Kehakiman.

Undang-Undang Nomor 16 Tahun 2004 tentang Kejaksaan.

Undang-Undang Nomor 16 Tahun 2006 tentang Pemerintahan Aceh.

Peraturan Daeah (Perda) Nomor 5 Tahun 2000 sebagai Pelaksanaan Syariat Islam.

Peraturan Gubernur Nomor 10 Tahun 2005 tentang Petunjuk Tehnis Pelaksanaan Uqubat Cambuk. 